UDK: 34(4-672EU)

Pregledni naučni rad

340.137(4-672EU)

Biblid: 1451-3188, 20 (2021)

Primljen 17.3.2021.

God XX, br. 75, str. 53-71

DOI: https://doi.org/10.18485/iipe_ez.2021.20.75.4

\title{
DIREKTIVE U PRAVNOM SISTEMU EVROPSKE UNIJE I NJIHOV PRENOS (TRANSPOZICIJA) U UNUTRAŠNJE PRAVNE SISTEME DRŽAVA ČLANICA
}

\author{
Dragoljub TODIĆ* \\ Ljubomir TINTOR**
}

Apstrakt: Osnovni cilj rada je ispitivanje mesta i uloge direktiva Evropske unije (EU) u pravnom sistemu ove organizacije u kontekstu obaveze njihovog prenošenja u unutrašnje pravne sisteme država članica. U radu se razmatra hipoteza da prenos direktiva nije jasno regulisan, što u nekim elementima ostavlja prostor za različita tumačenja i primenu, uključujući i pojavu neusaglašenosti unutrašnjeg prava sa normama iz direktive. Za polaznu osnovu analize se uzima sadržaj člana 288 Ugovora o funkcionisanju Evropske unije (UFEU), kao i druge relevantne odredbe ovog ugovora i Ugovora o Evropskoj uniji (UEU). Polazeći od specifičnosti koje direktive imaju kao izvori prava, raspravlja se o ključnim elementima od značaja za razumevanje obaveze prenosa direktiva u unutrašnje pravne sisteme (pojam i značaj „prenosa”, svrha, nadležnost organa EU, „rezultati koji treba da se postignu”, oblik i način prenosa, rokovi za prenos, obaveza izveštavanja Komisije itd.). Ukazuje se na praksu nekih država članica, kao i na neke teorijske pristupe i teškoće $u$ procesu prenosa direktiva. U zaključku se konstatuje da prenos direktiva u unutrašnje pravne sisteme predstavlja sistemsko pitanje koje bi trebalo preciznije regulisati imajući u vidu više činilaca (nadležnost ove organizacije, način donošenja direktiva, njihova primena i kontrola nad primenom, specifičnosti pravnih sistema

\footnotetext{
* Institut za međunarodnu politiku i privredu, Beograd.

E-mail: dtodic@ymail.com

Rad je nastao u okviru naučnoistraživačkog projekta „Srbija i izazovi u međunarodnim odnosima 2021. godine”, koji finansira Ministarstvo prosvete, nauke i tehnološkog razvoja Republike Srbije, a realizuje Institut za međunarodnu politiku i privredu tokom 2021. godine.

** Student doktorskih studija na Pravnom fakultetu Univerziteta u Beogradu, stipendista Ministarstva prosvete, nauke i tehnološkog razvoja RS.
}

E mail: ljubomir.tintor@yahoo.com 
Evropsko zakonodavstvo, br. 75/2021

država članica u koje se direktive prenose, specifičnosti materije koja je predmet uređivanja itd.).

Ključne reči: Evropska unija, direktive EU, prenos direktiva, transpozicija, usklađivanje unutrašnjih propisa, primena propisa EU, Sud pravde EU, države kandidati za članstvo

\section{1) DIREKTIVE U PRAVNOM SISTEMU EU}

U pravnom sistemu EU direktive imaju izvesne karakteristike zbog kojih zaslužuju posebnu pažnju. ${ }^{1}$ Više je pitanja koja bi se mogla postaviti kako sa normativnog stanovišta tako i u kontekstu duge istorije postojanja primene direktiva. ${ }^{2}$ Izvesne promene koje je uveo Lisabonski ugovor različito se tumače. ${ }^{3}$ Ipak,

\footnotetext{
${ }^{1} \mathrm{U}$ ovom radu se ne ulazi u posebnu raspravu o značenju formulacije „pravni sistem EU” već se, za potrebe analize, sadržajem ovog pojma smatraju, pre svega, formalni izvori prava EU i sa ovim povezane institucije. Za kritički osvrt na korišćenje formulacije „pravni sustav Europske unije” videti kod: Željko Horvatić, „Pravni sustav Europske unije i pravni temelj njegovog utjecaja na pravne sustave država članica Europske unije," Akademija pravnih znanosti Hrvatske, Vol. IV, 2013, str. 9-16.
}

${ }^{2}$ Dve najstarije direktive koje su i danas na snazi donete su 1962. godine i to su Direktiva Saveta o usklađivanju pravila država članica u vezi sa bojama odobrenim za upotrebu u hrani namenjenoj za prehranu ljudi (0J 115, 11.11.1962, pp. 2645-2654), koja je do sada amandirana 46 puta, i Direktiva o slobodi zapošljavanja stručnjaka u oblasti nuklearne energije (0J 057, 09.07.1962, pp. 1650-1652).

${ }^{3}$ Lisabonski ugovor smanjuje broj pravnih instrumenata na pet tradicionalnih instrumenata Zajednice (tj. tri obavezujuća i dva neobavezujuća). To su: uredba, koja ima opštu primenu i koja je obavezujuća u celosti i direktno primenjiva u svim državama članicama; direktiva, koja je obavezna u pogledu rezultata koje treba postići za svaku državu članicu kojoj je upućena, a nacionalnim vlastima se prepušta izbor oblika i načina; odluka koja je u celini obavezujuća, a odluka koja određuje one kojima je upućena obavezujuća je samo za njih; preporuka i mišljenje, koji nemaju obavezujuću snagu. Za šire videti: Jean-Claude Piris, The Lisbon Treaty - A Legal and Political Analysis, Cambridge University Press, 2010, pp. 93-94. Hofmann govori o devet različitih kategorija obavezujućih akata. Direktive (kao i uredbe i odluke) se „prema novoj tipologiji” mogu pronaći na „tri različita nivoa” i tri različita postupka donošenja. Prvi nivo obuhvata „zakonodavne akte," usvojene u redovnom zakonodavnom postupku iz člana 289 UFEU. Drugi nivo obuhvata "delegirane akte” u skladu sa članom 290 UFEU pod čim se podrazumevaju tzv. „nezakonodavni akti opšte primene za dopunu ili izmenu određenih nebitnih elemenata zakonodavnog akta". Na trećem nivou se nalaze tzv. sprovedbeni akti iz člana 291 UFEU za okolnosti kada je potrebno obezbediti „,jedinstvene uslove za sprovođenje pravno obavezujućih akata Unije." Dakle, osnovne kategorije obavezujućih akata (uredbe, direktive i odluke) koji se donose kao zakonodavni, delegirani ili sprovedbeni akti. Herwig Hofmann, "Legislation, Delegation and Implementation under the Treaty of Lisbon: Typology Meets Reality", European Law Journal, Vol. 15, No. 4/2009, p. 486. Pored ovih, članom 296 UFEU predviđen je, kao poseban pravni instrument, međuinstitucionalni sporazum; zatim, $\mathrm{u}$ 
procenjuje se da potpuno razumevanje ovih promena pretpostavlja razumevanje pred-lisabonskog pravnog okvira koji se odnosio na tzv. sprovedbena ovlašćenja i činjenice da „lisabonska reforma u području donošenja izvršnih pravila ne znači radikalni raskid sa pred-lisabonskom prošlošću, već se nadovezuje na nju...."

Od ukupno 659 direktiva koliko je na početku 2021. godine bilo na snazi u pravnom sistemu EU, oko dve trećine se odnosi na četiri velike oblasti. ${ }^{5}$ To su: „industrijska politika i unutrašnje tržište” (181), „životna sredina, potrošači i zaštita zdravlja” (134), „poljoprivreda” (130) i „sloboda kretanja radnika i socijalna politika” (79). ${ }^{6}$ Prema klasifikaciji koju primenjuje „EuroVoc", najveći broj direktiva pripada domenu „pravo EU” (izvori i grane prava, građansko, krivično, međunarodno, pravosuđe, organizacija pravosudnog sistema, prava i slobode) (164), zatim marketing (104), zdravstvena politika (99), tehnička pravila (99), agrarna politika (75), potrošači (68), radni uslovi (50) itd. Naravno, u zavisnosti od primenjenih kriterijuma klasifikacije, lista i broj direktiva po pojedinim grupama mogu izgledati i drugačije.

članu 216 govori se o međunarodnim sporazumima, a član 313 propisuje poseban zakonodavni postupak kada se utvrđuje godišnji budžet Unije. Za stavove drugih autora videti, npr: Nikoleta Yordanova, Asya Zhelyazkova, "Legislative Control over Executive Law-making: Delegation of Quasi-legislative Powers to the European Commission", JCMS: Journal of Common Market Studies, Vol. 58, No. 2/2020, pp. 345-364; Robert Schütze, “'Delegated' Legislation in the (new) European Union: A Constitutional Analysis", The Modern Law Review, Vol. 74, No. 5/2011, pp. 661-693.

${ }^{4}$ Merijn Chamon, „The legal framework for delegated and implementing powers ten years after the entry into force of the Lisbon Treaty", ERA Forum, 2021.

${ }^{5}$ https://eur-lex.europa.eu/search.html?qid=1610240840091\&name=browse-by\%3 Alegislation-in-force\&type=named\&displayProfile=allRelAllConsDocProfile\&FM_CODED=DIR. Ako se ovom broju dodaju i 16 sprovedbenih direktiva i 2 delegirane direktive, koje se posebno iskazuju, onda je ukupan broj direktiva 676, pristupljeno: 10.1.2021.

${ }^{6}$ Zatim slede direktive koje pripadaju sledećim grupama propisa: saobraćajna politika (71), „pravo poslovnog nastanjenja i pružanja usluga” (62), „sloboda, sigurnost i pravda” (46), „pravo koje se odnosi na preduzetnike” (29), „porezi” (28), „energetika” (14), „opšta finansijska i institucionalna pitanja” (8), ,ekonomska i monetarna politika i sloboda kretanja kapitala” (8), „nauka, informisanje, obarazovanje i kultura” (6), „carinska unija i slobodno kretanje robe” (6), ,,politika tržišne konkurencije” (6), ,evropa građana” (6), ,spoljni odnosi” (4), „regionalna politika i koordinacija strukturnih instrumenata” (2), „ribarstvo” (2) i „zajednička vanjska i bezbednosna politika" (1). Za šire videti: https://eur-lex.europa.eu/search.html?qid=1610 240840091\&name=browse-by\%3Alegislation-in-force\&type=named\&displayProfile=allRel AllConsDocProfile pristupljeno: 10.1.2021.

${ }^{7}$ Ipak, za razumevanje mesta koje direktive imaju u pravnom sistemu EU trebalo bi imati u vidu da ukupan broj pravnih akata EU ("EU law and case law") obuhvata 21.228 izvora prava i drugih relevantnih dokumenata (kako onih koji imaju obavezujući karakter tako i onih koji nisu obavezujući). Kada se ostave po strani „međunarodni sporazumi” (2.139) ostaje 19.089 
Kao što je već napomenuto, direktive se (kao i uredbe i odluke) donose u „redovnom" i „posebnom zakonodavnom postupku”. ${ }^{8}$ Prema odredbama člana 289 UFEU, redovan zakonodavni postupak sastoji se u tome što Evropski parlament i Savet zajednički donose direktivu, na predlog Komisije. ${ }^{9}$ U posebnom zakonodavnom postupku direktive (kao i uredbe i odluke) donosi Evropski parlament uz učešće Saveta ili Savet uz učešće Evropskog parlamenta. U nekim slučajevima predviđenim Ugovorima, zakonodavni akti mogu biti doneti i na inicijativu grupe država članica ili Evropskog parlamenta, na preporuku Evropske centralne banke ili na zahtev Suda pravde ili Evropske investicione banke (čl. 284 Stav 4). ${ }^{10}$

Direktive (kao jedan od izvora sekundarnog prava) imaju izvesne karakteristike koje ih čine pogodnim za primenu u različitim oblastima. One propisuju državama članicama obavezu ostvarivanja „rezultata koji treba da se postignu” ("result to be achieved"), koji su propisani konkretnom direktivom, dok im se ostavlja sloboda u pogledu „oblika i načina” ("form and methods”) kako će taj rezultat postići. ${ }^{11} \mathrm{U}$

„pravnih akata” među kojima su najbrojnije odluke i uredbe. U zavisnosti od vrste i organa nadležnih za donošenje broj odluka iznosi 8.624, čemu treba dodati i „sprovedbene odluke” (1.290), „okvirne odluke” (19) i „delegirane odluke” (17), koje se posebno iskazuju. Trenutno u pravnom sistemu EU postoji 3.035 „uredbi”, pored „sprovedbenih uredbi” (2.957) i "delegiranih uredbi” (408). Ostali akti EU nisu pravno obavezujući i obuhvataju preporuke, mišljenja, zaključke, smernice, izjave, izveštaje itd. Za šire videti: https://eurlex.europa.eu/search.html?qid=1610240840091\&name=browse-by\%3Alegislation-inforce\&type=named \&displayProfile=allRelAllConsDocProfile\&FM_CODED=DEC_ENTSCHEID, pristupljeno: 10.1.2021.

${ }^{8}$ Propisani način donošenja direktive može da predstavlja jedan od značajnijih elemenata koje bi trebalo imati u vidu u raspravi o prenosu direktiva u unutrašnje pravne sisteme i, naročito, uzrocima kršenja normi iz direktiva u unutrašnjim pravnim sistemima država članica. Međutim, zbog ograničenosti prostora ovde ne ulazimo u detaljniju analizu ovog pitanja.

${ }^{9}$ Detaljnija pravila ovog postupka propisana je u članu 294 UFEU.

${ }^{10}$ Pitanje uloge pojedinih organa u procesu donošenja direktiva zaslužuje posebnu analizu. Na sajtu EUR - Lex postoji mogućnost pretraživanja direktiva na osnovu dva kriterijuma koji su neposredno relevantni za pitanje donošenja. Najpre, prema „autoru” (Savet EU, Evropski parlement i Savet, Evropski parlament, Evropska komisija, ...), a potom prema „vrsti precedure” („suodlučivanje”, 177; „,redovni zakonodavni postupak”, 109, ,,konsultovanje”, 100 itd). https:// eur-lex.europa.eu/search.html?qid=1610240840091\&name=browse-by\%3Alegislation-inforce\&type=named\&displayProfile=allRelAllConsDocProfile\&FM_CODED=DIR , pristupljeno: 10.1.2021.

${ }^{11}$ Karakteristika koja je zajednička sekundarnim izvorima prava je da su oni podređeni primarnim izvorima, tj. nepoštovanjem primarnog izvora prava za sobom povlači nezakonitost relevantne odredbe sekundarnog prava. Sekundarni izvori prava obično se klasifikuju u tzv. tipične u koje se, prema članu 288 Ugovora o funkcionisanju EU (UFEU) ubrajaju uredbe, direktive, odluke, preporuke i mišljenja, pri čemu dva poslednja nemaju pravno obavezujuću snagu. Tzv. netipičnim aktima koji se spominju u UFEU smatraju se akcioni programi, 
literaturi se posebno naglašava značaj fleksibilnosti, kao ključne karakteristike direktiva EU, čime se državama članicama ostavlja izvesna sloboda u pogledu načina kako će određena pitanja urediti svojim unutrašnjim propisima, vodeći računa o specifičnostima konkretnog pravnog sistema i drugim okolnostima. Razlika između direktiva i drugih izvora prava EU (da direktive nisu odmah primenjive na nacionalnom nivou) podrazumeva potrebu da se one prenesu, tj. „inkorporiraju” u nacionalno pravo. ${ }^{12}$

Značaj rasprave o pitanju mesta i uloge direktiva u pravnom sistemu EU, kao i njihovog prenosa (transpozicije) u unutrašnje pravne sisteme država članica, trebalo bi posmatrati u kontekstu ukupne efikasnosti EU kao organizacije i preplitanja njenog pravnog sistema sa pravnim sistemima država članica. ${ }^{13}$ Steunenberg i Rhinard prenos direktiva označavaju „kritičnim preduslovom za efikasnu primenu Evropske politike". ${ }^{14}$ Bez odgovarajuće transpozicije, norme iz direktive neće biti na odgovarajući način integrisane u nacionalni pravni poredak zbog čega se pravna baština EU dovodi u rizik od neujednačene primene. Na širi kontekst transpozicije

komunikacije, međuinstitucionalni sporazumi i rezolucije. Gian Luigi Tosato, Leonardo Bellodi (Eds). EU Competition Law, Claeys \& Casteels Publishing, Deventer (The Netherlands) - Leuven (Belgium), 2015, p. 4. Za šire videti i kod: Gordana Gasmi, Pravo i osnovi prava Evropske unije, Univerzitet Singidunum, Beograd, 2010, 152. i dalje.

${ }^{12}$ Michael Kaeding, "Determinants of Transposition Delay in the European Union", Journal of Public Policy, Vol. 26, No. 3/2006, p. 232. Međutim, u vezi sa ovim praksa je postavila i nova pitanja u čijim odgovorima se nastoji zauzeti praktičan odnos prema pitanju direktne primene direktiva u unutrašnjim pravnim sistemima. Naročito u ranijem periodu, Sud pravde je koristio termine „direktna primenljivost” i „direktan efekat”. Oba termina označavaju direktnu izvršnost, što je učinilo razliku između ova dva koncepta zbunjujućom. Iako u praksi „direktni efekat" i "neposredna primenljivost” idu ruku pod ruku, direktni efekat treba shvatiti kao odvojen koncept od neposrednog primenjivanja. Upotreba izraza „direktno primenjiv" potiče iz sfere međunarodnog javnog prava, prema kojoj je odredba međunarodnog prava na snazi i primenjiva u nacionalnom pravnom sistemu bez potrebe da se prvo transponuje u nacionalno pravo. Odvojenim pitanjem smatra se pitanje da li se na tu odredbu može pozvati i pojedinac. Sonya Walkila, Horizontal Effect of Fundamental Rights in EU Law, Europa Law Publishing, Groningen 2016, p. 21. Za širu raspravu o ovim pitanjima videti kod: Koraljka Sansovic, „Koncepti izravne primjene i izravnog učinka u pravu Europske unije”, Croatian and Comparative Public Administration, Vol. 20, No. 2/2020, pp. 369-394. Za izvesne dileme u vezi sa „direktnom primenom direktiva” videti i kod: Žaklina Novičić. „Direktna horizontalna primena direktive i opšteg principa zabrane starosne diskriminacije - slučaj Mangold vs. Helm (2005)", Evropsko zakonodavstvo, br. 33-34/2010, str. 234-245.

${ }^{13}$ Za šire videti: Karen J. Alter, “The European Union's Legal System and Domestic Policy: Spillover or Backlash?", International Organization , Vol. 54, No. 3/Summer, 2000, pp. 489-518.

${ }^{14}$ Bernard Steunenberg, Mark Rhinard, "The transposition of European law in EU member states: between process and politics", European Political Science Review, Vol. 2, No. 3/2010, pp. 495-520. 
(kao „deo ... procesa primene politike”) ukazuje i Dimitrakopoulos. ${ }^{15}$ Kaeding raspravlja o „pravovremenoj, pravilnoj i potpunoj transpoziciji” koje smatra „ključnim za funkcionisanje pravnog sistema EU i država članica". Suprotno postupanje može da ima posledice na unutrašnje tržište, prouzrokujući „pravnu nesigurnost, podrivanje poverenja građana i privrednih subjekata u izvršavanje njihovih prava ....16 Pitanje prenosa direktiva u unutrašnji pravni sistem može imati poseban značaj u kontekstu usklađivanja prava država kandidata za članstvo u EU sa pravom EU. ${ }^{17}$ Moglo bi se govoriti o više razloga zbog čega se pitanje odnosa država kandidata za članstvo u EU, prema pitanju načina prenošenja direktiva u unutrašnji pravni sistem, može smatrati osetljivim. ${ }^{18}$ Ovo, utoliko više što se smatra da je sam postupak preuzimanja obaveza iz direktiva EU isti kako za period kandidature za članstvo tako i nakon sticanja članstva u EU. ${ }^{19} \mathrm{U}$ tom smislu bi rasprava o prenosu direktiva za Republiku Srbiju, kao kandidata za članstvo u EU (sa skoro dve decnije dugom praksom prenosa direktiva), mogla biti posebno interesantna. ${ }^{20}$

\section{2) PRENOS (TRANSPOZICIJA) DIREKTIVA U UNUTRAŠNJE PRAVNE SISTEME}

\subsection{POJAM I ZNAČAJ}

Pojam „prenošenje” direktiva EU različito se definiše, iako sadržaj i smisao pojma u osnovi ostaju na prvi pogled jednostavno prepoznatljivi. ${ }^{21} \mathrm{U}$ EU

${ }^{15}$ Dionyssis G. Dimitrakopoulos, D.G. "The Transposition of EU Law: 'Post-Decisional Politics' and Institutional Autonomy”. European Law Journal, Vol. 7, No. 4/2001, pp. 442-458.

${ }^{16}$ Michael Kaeding, “Determinants of Transposition Delay in the European Union”, op. cit., p. 229.

${ }^{17}$ Što zaslužuje posebnu i znatno detaljniju analizu.

${ }^{18}$ Za šire o nekim dilemama kada je u pitanju Srbija videti: Dragoljub Todić, "Harmonization of legislation of the Republic of Serbia with EU law: open issues and dilemmas", Review of international affairs, 1-2/2014, pp. 96-109.

${ }^{19}$ U slučaju Hrvatske to se eksplicitno konstatuje. „Postupak preuzimanja direktiva u uvjetima članstva identičan je usklađivanju u pretpristupnom razdoblju te prijedlozi zakona koji se usklađuje s direktivama u prilogu imaju ispunjenu Izjavu o usklađenosti prijedloga propisa i Usporedni prikaz podudaranja odredbi propisa." https://www.sabor.hr/hr/europskiposlovi/uskladivanje-zakonodavstva, pristupljeno: 3.1.2021.

${ }^{20} \mathrm{Za}$ šire o nekim dilemama kada je u pitanju Srbija videti: Dragoljub Todić, "Harmonization of legislation of the Republic of Serbia with EU law: open issues and dilemmas", Review of international affairs, 1-2/2014, pp. 96-109. Za informacije o planovima usklađivanja unutrašnjih propisa sa propisima EU videti: Ministarstvo za evropske integracije, Nacionalni program za usvajanje pravnih tekovina Evropske Unije - treća verzija, 2018. godina.

${ }^{21}$ Ovde se koristi izraz „prenos” za engleski izraz „transposition”, budući da se ovaj izraz koristi u srpskom jeziku kada se govori o direktivama. Videti, npr. dokument pod nazivom „Izvori prava 
terminologiji pojam „transpozicija” („prenošenje”) definiše se kao „postupak uključivanja direktiva EU u nacionalna prava država članica." ${ }^{22}$ U nekim specifičnim oblastima daju se i nešto detaljnije definicije, pa se pod pojmom "transpozicija” podrazumeva „svaka zakonodavna, regulatorna ili administrativno obavezujuća mera koju je preduzelo bilo koje nadležno telo države članice kako bi se u nacionalni pravni poredak ugradile obaveze, prava i dužnosti sadržane u EU direktivama ...."23 Istovremeno, pojam "transpozicija” se koristi i za oznaku procesa, tj. za „odabir odgovarajućih oblika i načina za postizanje rezultata traženih direktivom. ${ }^{24} \mathrm{Za}$ potrebe ove rasprave, definisanje značenja i smisla "prenošenja” direktive u unutrašnji pavni sistem bi verovatno bilo najuputnije držeći se razumevanja procesa koji se u literaturi i praksi obično označavaju kao „usklađivanje”, „harmonizacija” ili „aproksimacija” unutrašnjih propisa sa propisima EU. ${ }^{25}$ Ovo bez obzira što su poslednji pojmovi širi i što bi međusobne odnose sa „prenosom” direktiva trebalo detaljnije analizirati.

Za razumevanje pojma prenos (transpozicija) direktiva može biti relevantna i činjenica da Ugovor o Evropskoj uniji (UEU) ne definiše ovaj pojam na poseban

EU" na sajtu nadležnog organa https://www.mei.gov.rs/upload/documents/nacionalna_ dokumenta/instrumenti_za_uskladjivanje_propisa/izvori_prava_eu.pdf (15.1.2021); ili prevod člana 260 UFEU na srpski jezik - Prečišćene verzije Ugovora o Evropskoj uniji i Ugovora o funkcionisanju Evropske unije https://www.mei.gov.rs/upload/documents/eu_dokumenta/ ugovor_o_eu_i_funkcionisanju_eu_prociscena_verzija_jul_20.pdf (15.1.2021). Isto i u slučaju prevoda na hrvatski jezik http://www.mvep.hr/custompages/static/hrv/files/pregovori/111 221-lisabonski-prociscena.pdf (15.1.2021). U odlukama o instrumentima za usklađivanje zakonodavstva Republike Hrvatske s pravnom stečevinom Europske unije iz 2011. godine (NN, br. 93/2011) (dakle, pre sticanja člnastva u EU) i 2017. godine (NN, br. 44/2017) (nakon sticanja članstva u EU) koriste se i formulacije „prenos” i „preuzimanje”. Interesantno je da rečnik „engleske pravne terminlogije" ne prepoznaje termin "transposition” kao poseban termin. Kada se govori o direktivama u rečniku se pojam "transposing" vezuje za izbor formi i metoda za prenos ciljeva direktiva u nacionalno pravo. Helen Gubby, English legal terminology, Legal concepts in language, Eleven International Publishing, The Hague, 2016, p. 90. U rečniku je reč "harmonisation” izjednačena sa rečju “approximation”, pod čime se označava „usklađivanje (ili približavanje): radi usklađivanja zakona različitih država članica.”, Ibid., p. 114.

22 "Transposition", https://eur-lex.europa.eu/summary/glossary/transposition.html?locale=en, pristupljeno: 24.01.2021.

${ }^{23}$ Guide to the Approximation of European Union Environmental Legislation, https://ec. europa.eu/environment/archives/guide/annex4.htm, pristupljeno: 3.1.2021.

${ }^{24}$ Bernard Steunenberg, Wim Voermans, The transposition of EC directives: A Comparative Study of Instruments, Techniques and Processes in Six Member States, Leiden University, Leiden/ Research and Documentation Centre (WODC) of the Ministry of Justice, The Hague, 2005, p. 9.

${ }^{25}$ Za širi pregled dilema u vezi sa ovim videti kod Radovan Vukadinović, „Od ugledanja na jevropejske uzore do regionalne harmonizacije - druga strana medalje", Revija za evropsko pravo, Vol. 17, No. 1/2015, str. 5-26. 
način. U članu 260 UFEU (bivši član 228 UEZ) govori se o „merama za prenošenje direktive koje su donete u skladu sa zakonodavnim postupkom.." ${ }^{26}$ I u nekoliko drugih odredbi UFEU govori se o „prenošenju”. Na opšti način je to učinjeno, na primer, u članu 4 stav 3 gde je propisano da "države članice preduzimaju sve odgovarajuće mere, opšte ili posebne, kako bi obezbedile ispunjenje obaveza koje proizilaze iz Ugovorâ ili iz akata organâ Unije." Istovremeno, članom 291 UFEU države članice su se obavezale da "usvajaju sve mere nacionalnog prava neophodne za sprovođenje pravno obavezujućih akata Unije" (stav 1).

\subsection{KLJUČNI ELEMENTI}

Sadržaj člana 288 UFEU, kao i druge sa ovim povezane odredbe UFEU i UEU, ističu u prvi plan nekoliko elemenata od značaja za tumačenje prava i obaveza i vezi sa prenosom direktiva. U nastavku se ukazuje na neke od njih.

\subsubsection{Svrha donošenja - „vršenje nadležnosti Unije"}

Svrha donošenja direktiva je „vršenje nadležnosti Unije” i ovakva formulacija jasno upućuje na potrebu da se pri tumačenju sadržaja direktiva i načina njihovog prenosa ima u vidu „nadležnost Unije." ${ }^{27} \mathrm{Za}$ ove potrebe bi moglo biti korisno ograničiti se i razlikovati dve vrste nadležnosti, koje su međusobno povezane. U slučaju nadležnosti za donošenje zakonodavnih akata, u skladu sa članom 2 UFEU, kada je Ugovorima Uniji poverena isključiva nadležnost u određenoj oblasti, propisano je da samo Unija može da deluje kao zakonodavac i da usvaja pravno obavezujuće akte, a države članice to mogu samo ako ih je za to ovlastila Unija ili radi sprovođenja akata Unije..$^{28} \mathrm{~S}$ druge strane, kada je Ugovorima Uniji poverena nadležnost koju ona deli sa državama članicama u određenoj oblasti, Unija i države članice mogu da deluju kao zakonodavci i usvajaju pravno obavezujuće akte u toj oblasti (čl. 2 st. 2 UFEU). ${ }^{29}$

\footnotetext{
${ }^{26} \mathrm{U}$ stavu 3 ovog člana propisuje se mogućnost koja se daje Komisiji (kada uputi predmet Sudu u skladu sa članom 258 na osnovu toga što država članica nije ispunila svoju obavezu da obavesti o merama za prenošenje direktive), da „ako to smatra primerenim, odredi visinu paušalnog iznosa ili penala koje država članica treba da plati, a koje smatra primerenim s obzirom na okolnosti.” Dalje se kaže da „Ako Sud ustanovi da je došlo do povrede, on može datoj državi članici naložiti plaćanje paušalnog iznosa ili penala koji ne prelaze iznos koji je odredila Komisija."

${ }^{27}$ U članu 288 UFEU se kaže „radi vršenja nadležnosti Unije”.

${ }^{28}$ Kada se govori o isključivoj nadležnosti Unije UFEU ima u vidu sledeće oblasti: a) carinska unija; b) utvrđivanje pravila konkurencije neophodnih za funkcionisanje unutrašnjeg tržišta; v) monetarna politika za države članice čija je valuta evro; g) očuvanje bioloških resursa mora u okviru zajedničke politike u oblasti ribarstva; d) zajednička trgovinska politika (čl. 3 UFEU).

${ }^{29}$ U slučaju „podeljene nadležnosti Unije i država članica” ona obuhvata sledeće glavne oblasti: a) unutrašnje tržište; b) socijalna politika, u aspektima utvrđenim u ovom ugovoru; v)
} 


\subsection{2. "Organi” EU}

Kada govori o direktivama u članu 288 UFEU se kaže da ih donose „organi”. U članu 13 UEU propisano je da su organi Unije Evropski parlament, Evropski savet, Savet, Evropska komisija (u daljem tekstu: Komisija), Sud pravde Evropske unije, Evropska centralna banka i Revizorski sud. Evropski parlament, zajedno sa Savetom, vrši zakonodavnu i budžetsku funkciju (čl. 14 st. 1). Ipak, u raspravama o donošenju direktiva najčešće se imaju i vidu nadležnosti Evropskog parlamenta, Saveta i Komisije iako i drugi organi mogu imati određenu ulogu (Evropska centralna banka, Sud pravde i Evropska investiciona banka). ${ }^{30}$

U literaturi se posebno razmatraju pitanja koja se odnose na nadležnost pojedinih tela unutar država članica, dinamiku prenosa, uzroke kašnjenja u prenosu (u odnosu na rokove koje propisuju direktive), posledice takvog stanja i aktivnosti Komisije i Suda pravde EU u vezi sa tim. ${ }^{31}$ Steunenberg i Rhinard u svojoj analizi ukazuju na teškoće organa u pojedinim državama u procesu prenosa direktiva EU, polazeći od transpozicije kao "glavne tačke šireg programa istraživanja neusklađenosti propisa u EU." Ističući nekoliko popularnih objašnjenja (napominjući da se ponekad dobijaju i kontradiktorni rezultati koji proizlaze iz empirijskog testiranja), autori transpoziciju vide kao proces koji se uglavnom odvija unutar agencija, a ne kroz sistem vladinih organa. ${ }^{32}$ Steunenberg i Kaedin transpoziciju direktiva EU razmatraju u kontekstu nekoliko „varijabli” (determinanti) koje uslovljavaju dinamiku i kvalitet ovog procesa. Argument koji se ovde koristi jeste da je direktive Komisije jednostavnije preneti nego direktive Saveta i Parlamenta, jer su često fokusirane na politički manje kontroverzna i više tehnička pitanja. ${ }^{33}$

ekonomska, socijalna i teritorijalna kohezija; g) poljoprivreda i ribarstvo, sa izuzetkom očuvanja bioloških resursa mora; d) životna sredina; đ) zaštita potrošača; e) transport; ž) transevropske mreže; z) energetika; i) prostor slobode, bezbednosti i pravde; j) zajednička pitanja bezbednosti u oblasti javnog zdravlja, u aspektima utvrđenim u ovom ugovoru (čl. 4 st. 2 UFEU).

${ }^{30}$ Za šire o nadležnosti Komisije videti kod: Zoran Radivojević, „Nadležnost Komisije u postupku predlaganja, usvajanja i sprovođenja akata organa Evropske unije", Revija za evropsko pravo, Vol. 18, No. 1/2016, str. 69-92.

${ }^{31}$ Nora Dorrenbacher et. al., "National Parliaments and Transposition of EU Law: A Matter of Coalition Conflict", Journal of Common Market Studies, Vol. 53, No. 5, September 2015, pp. 10101026; Martha Thomas, "The efficiency of ministries in transposing EU directives: Evidence from Ireland", Public Policy and Administration, Vol. 33, No. 2/2018, pp. 190-215.

${ }^{32}$ Bernard Steunenberg, Mark Rhinard, "The transposition of European law in EU member states: between process and politics", op. cit., pp. 495-520.

${ }^{33}$ Bernard Steunenberg, Kaeding Michael, "As time goes by': Explaining the transposition of maritime directives", European Journal of Political Research, Vol. 48/2009, p. 435. 


\subsection{3. "Rezultati koji treba da se postignu”}

Već na prvi pogled može da izgleda da je odredbama trećeg stava člana 288 UFEU relativno jasno propisana obaveza država članica kojima je direktiva upućena. One imaju obavezu da obezbede ostvarivanje „rezultata koji treba da se postignu” svakom konkretnom direktivom. Operacionalizacija ovakve obaveze prepuštena je svakoj od preko šest stotina direktiva u čijem procesu donošenja države članice učestvuju, u skladu sa načinom kako je propisano donošenje direktiva. Ipak, pitanje šta se smatra „rezultatima koji treba da se postignu” moglo bi biti predmet za izvesnu raspravu, kako na opštem nivou tako i u slučaju svake konkretne direktive. Najpre, bi se moglo postaviti pitanje vremena u kojem rezultati treba da se postignu. Kod onih obaveza iz direktiva gde su već propisani konkretni rokovi stvar izgleda relativno jednostavna. Početak primene direktive i neki rokovi za ostvarivanje rezultata u primeni propisani su direktivama i tu ne bi trebalo da bude posebnih dilema. Neke obaveze imaju trajni karakter, tj. važe sve dok se ne ukinu nekom drugom direktivom. Ali, jedan deo obaveza iz direktive nema takav karakter. Naravno, formulacija iz člana 288 UFEU upućuje i na to da bi se o odnosu države prema obavezama moglo prosuđivati tek nakon protoka određenog vremena od momenta stupanja na snagu direktive i konkretnih obaveza iz direktive za koje su rokovi propisani. Dakle, momenat prenosa direktive sam po sebi predstavlja samo prvu pretpostavku.

Osim vremenskog elementa koji je sastavni deo formulacije „rezultati koji treba da se postignu", tj. vremena koje je potrebno za ostvarivanje rezultata, odnosno procenu da li su oni ostvareni, iz ovakve formulacije proističe i pitanje šta bi se sve moglo smatrati „rezultatima koji treba da se postignu”, odnosno na osnovu čega bi se procenjivalo da li su oni „postignuti”. Pravilan prenos direktive ponovo dobija na značaju. Ali, čak i uz pretpostavku da je kopiran sadržaj direktive i kao takav prenet u unutrašnje propise, pitanje razumevanja ostvarenih rezultata nas vraća na pitanje tumačenja sadržaja normi iz direktive. Ako se za trenutak zadržimo samo na normativnom aspektu, postavlja se pitanje na osnovu kojih normi iz direktive procenjivati šta su to „rezultati koji treba da se postignu." Naravno, u slučaju nekih normi iz direktiva to je relativno jasno, ali kod nekih direktiva to može biti suočeno sa različitim očekivanjima. Ovo posebno kada se radi o direktivama koje uređuju složena pitanja kojima se zadire u interese brojnih subjekata iz različitih sfera privrede i društva i gde se očekivani rezultati mogu vezivati za duge vremenske periode.

Pored vremenske komponente formulacije, mnogo složenijim se čini materijalni element. Jednom od krajnjih okolnosti bi se mogla smatrati situacija kada se može postaviti pitanje šta čini rezultat onda kada su preduzete sve mere a rezultat nije postignut ili postoje sumnje u to. U ovakvim situacijama bi ocena "rezultata" verovatno trebalo da bude podvrgnuta konkretnim kriterijuma (ako postoje), $\mathrm{u}$ kontekstu ciljeva u celini i okolnosti konkretne direktive. Kod ostvarivanja 
konkretnih rezultata (u pogledu poštovanja standarda, normi itd.) može biti relativno jasno (pogotovo tamo gde su propisani kvantitativni parametri koji moraju biti poštovani od strane države članice nakon propisanog roka). Međutim, pitanje tumačenja i ostvarivanja rezultata nekih drugih delova direktive može predstavljati osnov za raspravu, posebno u direktivama sa puno elemenata koji liče na tzv. meko pravo i pravnu filozofiju.

„Rezultati koji treba da se postignu” merama koje su propisane konkretnom direktivom uvek bi trebalo da, na neki način, obuhvataju i ciljeve i/ili svrhu direktive, iako pitanje odnosa između „ciljeva” i „rezultata koji treba da se postignu” ima i dinamičke elemente u sebi.

Pri tome se stvar do izvesne mere može komplikovati zbog potreba da se razlikuju različite vrste ciljeva koji bi mogli biti relevantni u određenoj oblasti. Otuda se i kod tumačenja "ciljeva” moraju uzeti u obzir odredbe direktive u celini, uključujući „svrhu”, „predmet regulisanja”, definicije pojmova itd. ${ }^{34}$ Ovo nas dalje upućuje na potrebu sagledavanja opšteg konteksta materije koja je predmet regulisanja konkretnom direktivom čijim najvernijim odrazom bi se, najčešće, mogao smatrati sadržaj preambularnog dela direktive. ${ }^{35}$ Međutim, složenost ovako tumačenog odnosa između „cilja” i „rezultata koji treba da se postignu” naročito je potencirana činjenicom da oni mogu (eksplicitno ili indirektno) da zadiru u sektorske politike u drugim oblastima od značaja za ono što reguliše konkretna direktiva. U nekim slučajevima složenost rasprave o „rezultatima koji treba da se postignu" proističe i iz činjenice da neke direktive eksplicitno upućuju na druge propise ili direktive na način da takvo upućivanje na te druge propise znači i direktno preuzimanje obaveza koje su propisane tim drugim direktivama (uključujući i one koje su neposredno relevantne za „rezultate koji treba da se postignu”). ${ }^{36}$

\footnotetext{
${ }^{34}$ Npr. „svrha” Direktive 2005/36/EZ o priznavanju stručnih kvalifikacija definisana je članom 1 kao: „propisivanje pravila za pristup i obavljanje profesije, na temelju kojih države članice koje pristup regulisanim profesijama i njihovo obavljanje na svom državnom području uslovljavaju posedovanjem određenih stručnih kvalifikacija (dalje u tekstu „država članica domaćin”) priznaju stručne kvalifikacije stečene u drugim državama članicama (dalje u tekstu „matična država članica”), koje nosiocu omogućuju obavljanje iste profesije kao u matičnoj državi članici.”

${ }^{35}$ Uvodni (preambularni) deo direktive ponekad sadrži i neke formulacije koje liče na preporuke i čije mesto u oceni „rezultata koji treba da se postignu” može biti zbunjujuće. Npr. u preambuli Direktive 2013/33/EU o utvrđivanju standarda za prihvat podnosilaca zahteva za međunarodnu zaštitu se na nekoliko mesta koristi formulacija „trebalo bi" ili „treba”.

${ }^{36}$ Na primer: Direktiva 2008/50/EZ o kvalitetu ambijentalnog vazduha na različite načine upućuje na 27 drugih sekundarnih izvora prava obavezujućeg karaktera, među kojima je i 19 direktiva od kojih jedan broj u međuvremenu zamenjen novim izvorima prava EU. To bi trebalo da znači da „rezultati koji treba da se postignu” jednom direktivom treba da uključe i „rezultate koji treba da se postignu" koji su propisani tim drugim direktivama. Dodatne teškoće bi mogle da nastanu budući da prenos takvih vrsta normi u unutrašnje pravne sisteme može da bude
} 


\subsubsection{Oblik i način prenosa}

Kao što je već naznačeno, o „obliku i načinu” prenošenja direktive u unutrašnji pravni sistem odlučuje svaka država članica EU pojedinačno. Král u svom radu ispituje slobodu izbora država članica u pogledu metoda prenošenja direktiva EU, navodeći nekoliko činilaca koji je ograničavaju, a čija je osnova u pravu EU, odnosno nacionalnim pravnim sistemima država članica. ${ }^{37}$ Autor, analizirajući glavne metode prenošenja direktiva EU (kopiranje, razrada, minimalističko prenošenje i prenošenje kroz ugradnju viših standarda u odnosu na one koje direktiva propisuje), ukazuje na to da se izbor između glavnih metoda transpozicije „nikada ne može sprovesti na mehanički način." ${ }^{38}$ Umesto toga, prenos bi trebalo da se temelji na „sistemskoj i ciljnoj analizi sadržaja predmetne direktive, relevantnih nacionalnih propisa i direktno primenjivih pravnih akata EU." Ovome bi trebalo dodati i izbor političkih opcija u određenoj oblasti. ${ }^{39}$

U metodologiji prenosa direktiva razlikuju se „pravni instrumenti” kojima se prenose odredbe direktive i „tehnike” prenosa. U nekim slučajevima se koristi krajnje široko poimanje ovih pojmova. Tako se pod "pravnim instrumentima” podrazumevaju različite forme propisa (od zakona koje donose najviša zakonodavna tela, preko propisa koje donosi vlada i propisa nadležnih ministarstva, propisa koji donose pokrajine i lokalni organi vlasti, do akata koje donose privredne organizacije koje imaju takve nadležnosti, pa čak i akata koji ne sadrže opšte obavezujuća pravila), što bi moglo biti predmet posebne analize.$^{40}$ Kada se govori o "tehnikama” prenosa autori govore o prenosu „1 na 1" (doslovno kopiranje dela teksta direktive u unutrašnjem propisu države članice), doslovan prenos sa izvesnim manjim terminološkim promenama ili prilagođavanjem, prenos kroz postojeći pravni režim (ako za prenos nije potrebno usvajanje novog propisa, i prenos kroz ugrađivanje direktive u postojeći pravni režim (kroz „razradu” ili „elaboraciju”). ${ }^{41}$

sproveden korišćenjem različitih „oblika i načina”, što na nacionalnom nivou može da otvori pitanje najpodesnijeg (najfunkcionalnijeg) odnosa između upotrebljenih „oblika i načina” i „rezultata koji treba da se postignu,” kao i pitanje „rezultata koji treba da se postignu” u okviru propisa različitih po svom karakteru i dometu.

${ }^{37}$ Richard Král, "On the Choice of Methods of Transposition of EU Directives", European Law Review, Vol. 41, No. 2/2016, pp. 220-242.

${ }^{38}$ Ibid.

${ }^{39}$ Ibid.

${ }^{40}$ Bernard Steunenberg \& Wim Voermans, The transposition of EC directives: A Comparative Study of Instruments, Techniques and Processes in Six Member, op. cit., p. 9.

${ }^{41}$ Unutar ovih tehnika može se razlikovati više pristupa: prenos referenciranjem (tj. upotreba „statističkih i dinamičkih referenci na odredbe direktive”); aneks metoda, što znači da je direktiva uključena kao dodatak nacionalnoj meri prenošenja; direktna transpozicija i korišćenje transpozicije kao sredstva za dodatnu nacionalnu politiku. Ibid. 
Pristup država članica EU prema pitanju načina prenosa je različit. Ujedinjeno kraljevstvo, dok je ova država bila članica EU, preporučivalo je da se „uvek koristi metod kopiranja gde je to raspoloživo, osim kada bi to negativno uticalo na interese Ujedinjenog kraljevstva...." ${ }^{42}$ Kopiranjem se minimizira rizik od nepotpunog ili netačnog prenosa koji bi mogao dovesti do postupka za povredu prava protiv države članice koji preduzima Evropska komisija. Ova činjenica, kao i vremenski pritisak i opterećenje, pridoneli su (u novije vreme) povećanoj upotrebi kopiranja čak i u državama članicama koje su tradicionalno pokušavale preneti norme EU na takav način da osiguraju da se odredbe prirodno i neometano uklapaju u nacionalni pravni okvir ${ }^{43} \mathrm{Na}$ opasnosti od primene metoda "ponavljanja teksta direktive” ukazuje se i kod drugih autora. Negde se to stavlja u kontekst obaveze pravilne primene i kontrole primene, uz korišćenje kriterijuma efikasnosti. ${ }^{44}$

Na prenos normi iz direktive, u okviru procesa usaglašavanja unutrašnjih propisa sa propisima EU, Evropska komisija gleda kao na jedan od tri ključna elemenata. Primena normi iz direktive koje su prenete u unutrašnje pravne sisteme je drugi element koji, u nekim slučajevima, može biti izuzetno komplikovan naročito kada je za primenu neke norme neophodno koordinisano nastupanje različitih subjekata. Trećim elementom procesa usklađivanja unutrašnjih pravnih sistema sa propisima EU smatra se mehanizam nadzora i kontrole koji obuhvata sve mere čiji je cilj da se obezbedi poštovanje normi iz unutrašnjeg propisa kojim su prenete norme iz direktive. ${ }^{45}$

\subsubsection{Rokovi prenosa i obaveza izveštavanja Komisije}

Članom 288 UFEU propisano je da rokovi za prenos direktive i obaveza izveštavanja Komisije predstavljaju poseban element u postupku prenosa. Budući da je ovo i obavezan deo sadržaja pojedinačnih direktiva to u tumačenju ove vrste

\footnotetext{
${ }^{42}$ Ellen Heinemann, "The production process of EU directives and their transposition into national law - additional considerations reviewing 'Observing Eurolects. Corpus analysis of linguistic variation in EU law'", Laura Mori (ed.) Amsterdam/Philadelphia, John Benjamins 2018, p. 4, https://kups.ub.uni-koeln.de/10314/1/heinemann-2019-directives-transpositionreview-eurolects.pdf, pristupljeno: 20.1.2021. Za detaljnije pogledati i HM Government, „Transposition Guidance - How to implement European Directives effectively”, Crown, February 2018. https://www.gov.uk/government/publications/implementing-eu-directivesinto-uk-law, pristupljeno: 30.1.2021.

${ }^{43}$ Ellen Heinemann, op. cit., p. 4.

${ }^{44}$ Hulla \& Co Human Dynamics (Ed.), Handbook on the Implementation of EU Environmental Legislation; EKRAN - Environment and Climate Regional Acession Network; Hulla \& Co Human Dynamics 2015-2016, p. 23-24.

${ }^{45}$ Guide to the Approximation of European Union Environmental Legislation, https://ec.europa. eu/environment/archives/guide/part1.htm, pristupljeno: 3.1.2021.
} 
obaveza ne bi trebalo da bude posebnih dilema. Takođe, odredbama direktive propisuje se i obaveza nacionalnih tela da obaveste Evropsku komisiju o merama koje su države usvojile, nakon čega Evropska komisija proverava potpunost i pravilnost prenošenja direktiva u nacionalno zakonodavstvo. U skladu sa članom 260 UFEU, kada Komisija uputi predmet Sudu na osnovu toga što država članica nije ispunila obavezu da obavesti o merama za prenošenje direktive donete u skladu sa zakonodavnim postupkom, može (ako to smatra primerenim), odrediti visinu paušalnog iznosa ili penala koje država članica treba da plati (st. 3) ${ }^{46}$

\subsection{NEPOŠTOVANJE OBAVEZA U VEZI SA PRENOSOM DIREKTIVA}

Uloga Komisije i Suda pravde Evropske unije posebno je propisana. Komisija, ako smatra da država članica nije ispunila neku od obaveza na osnovu Ugovora, o tome daje obrazloženo mišljenje, nakon što toj državi da priliku da se izjasni (čl. 258). Ako država ne postupi u skladu sa mišljenjem u roku koji odredi Komisija, Komisija može uputiti predmet Sudu pravde Evropske unije. U dosadašnjoj praksi izgleda da se Evropska komisija bavila prevashodno pitanjem kašnjenja u transpoziciji, uzrocima i posledicama takvog stanja. ${ }^{47}$ Nepoštovanje propisa EU,

\footnotetext{
${ }^{46}$ Sud smatra da se „obaveza prijavljivanja mera kojima se prenosi direktiva”, u smislu člana 260 stav 3 UFEU-a, odnosi na obavezu država članica da dostave dovoljno jasne i precizne informacije o merama kojima se prenosi direktiva. Da bi se zadovoljila obveza pravne sigurnosti i osiguralo potpuno prenošenje odredbi te direktive na celo njeno područje, države članice moraju za svaku odredbu direktive navesti nacionalnu odredbu ili odredbe koje osiguravaju njeno prenošenje. „Annual Report 2019: Judicial Activity”, Court of Justice of the European Union, Luxembourg, 2020, p. 34.
}

${ }^{47}$ Michael Kaeding, "Determinants of Transposition Delay in the European Union”, op. cit., pp. 229253; Thomas Konig, Luetgert, Brooke, "Troubles with Transposition? Explaining Trends in Member-State Notification and the Delayed Transposition of EU Directives", B. J. Pol. S., Vol. 39, No. 1/2009, pp. 163-194; Brooke Luetgert, Tanja Dannwolf, "Mixing Methods: A Nested Analysis of EU Member State Transposition Patterns", European Union Politics, Vol. 10, No. 3/2009, pp. 307-334; Asya Zhelyazkova, Nikoleta Yordanova, "Signalling 'Compliance': The Link between Notified EU Directive Implementation and Infringement Cases", European Union Politics, Vol. 16, No. 3/2015, pp. 408-28. Komisija je 2019. godine pokrenula 797 slučaja prekršaja, najveći broj u oblasti životne sredine (175), zatim slede unutrašnje tržište, industrija, poduzetništvo i mala i srednja poduzeća (147), mobilnost i transport (83). Na kraju 2019. godine ostalo je otvoreno 1.564 postupka za povredu prava. Broj novih slučajeva zbog kašnjenja u transpoziciji ostao je približno isti, sa 406 novih slučajeva u 2019. u odnosu na 419 u 2018. godini.

https://ec.europa.eu/info/publications/2019-commission-report-and-factsheets-monitoringapplication-eu-law_en, pristupljeno, 30.1.2021. Za šire videti godišnje izveštaje Evropske komisije. Za šire kada su u pitanju direktive koje odnose na jedinstveno evropske tržište, videti: https://ec.europa.eu/internal_market/scoreboard/performance_by_governance_tool/transpo sition/index_en.htm pristupljeno, 30.1.2021. 
posebno u delu koji se odnosi na transpoziciju nije povezano jedino sa rokovima transpozicije. Osim poštovanja roka, Falkner govori o još dva kriterijuma: pitanje obima (opsega) (da li su standardi preneti „u odgovarajućoj meri”) i pitanje načina (da li su standardi EU preneti na „,ispravan način”). ${ }^{48}$ To uključuje i pitanje postupka prema državi članici koja nije prenela direktivu u unutrašnji pravni sistem u propisanom roku, odnosno na potpun način. ${ }^{49}$ Različiti su podaci o neusaglašenosti. Tako, autori Thomson, Torenvlied i Arregui navode da je prema Europskoj komisiji, krajem 1982. godine bilo je na snazi 640 direktiva sa prosečnom stopom prenošenja od $89,58 \%$. U 2002. godini na snazi je bilo 2.240 direktiva s prosečnom stopom prenošenja od 98,87\%. Uz to, Europski sud pravde izvestio je da je 2004. godine ustanovio ukupno 114 prekršaja koji se tiču četrnaest država članica (sve stare države članice, osim Danske). ${ }^{50}$

\section{3) ZAKLJUČAK}

Mesto i ulogu direktiva u pravnom sistemu EU i država članica ove organizacije (pre svega zbog njihove obaveze prenosa u unutrašnje pravne sisteme), trebalo bi sagledavati u kontekstu potrebe za uvažavanjem različitosti pravnih sistema, privrede, tradicija, kultura itd. država članica organizacije, s jedne strane, i ostvarivanja ciljeva EU kao organizacije, s druge strane. U tom smislu „rezultat koji treba da se postigne" prenosom i primenom direktive ima karakter opšte obaveze, a izbor „oblika i načina” prenosa direktive pripada domenu slobode država članica. U radu je dokumentovana hipoteza da postojeći pravni okvir kojim se reguliše

${ }^{48}$ Gerda Falkner, et. al., Complying with Europe - EU Harmonisation and Soft Law in the Member States, Cambridge University Press, 2005, p. 4.

${ }^{49}$ Ovde se interesantnom čini analiza „deficita transpozcije” i „postupaka kršenja” na osnovu vremenskih serija između 1997. i 2016. godine (deficit transpozicije) i 2003. i 2016. godine (postupci kršenja) koju su radili Pircher i Loxbo i čiji nalazi sugerišu zaključak da postoji „snažna tendencija konvergencije između ponašanja država članica EU u pogledu usklađenosti.” Autori konstatuju postojanje „smanjenja deficita transpozicije i postupaka za kršenje propisa” što se „suprotstavlja ideji da je dezintegracija u obliku nepoštovanja trajni proces u EU. To radije ukazuje na to da je zakonodavstvo EU postalo usklađenije." Autori odbacuju tezu da ekonomski činioci, kapaciteti nadležnih organa i domaća politika deluju u pravcu odvajanja od procesa EU integracija i zaključuju da „snažni trend usklađenosti verovatno objašnja promenjenom kulturom prenošenja i sprovođenja”. Brigitte Pircher, Karl Loxbo, "Compliance with EU Law in Times of Disintegration: Exploring Changes in Transposition and Enforcement in the EU Member States between 1997 and 2016", Journal of Common Market Studies, Vol. 58, No. 5/2020, pp. 1270-1287.

${ }^{50}$ Robert Thomson, René Torenvlied, Javier Arregui, “The Paradox of Compliance: Infringements and Delays in Transposing European Union Directives", British Journal of Political Science, Vol. 37, No. 4/2007, p. 686. 
prenos direktiva u unutrašnje pravne sisteme nije potpuno jasan i da to u nekim elementima može imati za posledicu pojavu neusaglašenosti unutrašnjeg prava sa normama iz direktive. Ovo, posebno u delu koji se odnosi na procenu „rezultata koji treba da se postigne” i „oblik i način“ prenosa. Potrebu dogradnje postojećeg sistema prenosa direktiva (pre svega u delu koji se odnosi na "rezultat koji treba da se postigne" $i$ „oblik i način" prenosa) ima smisla tražiti vodeći računa o složenom procesu koji obuhvata i druga dva elementa od značaja za funkcionisanje pravnih sistema EU i država članica: primenu direktiva i kontrolu nad primenom. To, naravno, uključuje i neophodnost sagledavanja drugih sistemskih pitanja koja mogu da uslovljavaju nastanak problema u prenosu direktiva (od kašnjenja u prenošenju u odnosu na direktivom propisane rokove, preko nepotpunog i nepravilnog prenošenja itd.), kao što su način donošenja direktiva, odnos između pojedinih organa, veze koje direktive (kroz prenos) uspostavljaju sa specifičnostima funkcionisanja pravnih sistema država članica EU itd.

\section{4) LITERATURA}

Alter, Karen J. "The European Union's Legal System and Domestic Policy: Spillover or Backlash?", International Organization, Vol. 54, No. 3/Summer, 2000, pp. 489-518.

Chamon, Merijn, "The legal framework for delegated and implementing powers ten years after the entry into force of the Lisbon Treaty", ERA Forum, 2021.

"Annual Report 2019, Judicial Activity", Court of Justice of the European Union, Luxembourg, 2020, p. 34.

Dimitrakopoulos, Dionyssis G. D. G., "The Transposition of EU Law: 'Post-Decisional Politics' and Institutional Autonomy", European Law Journal, Vol. 7, No. 4/2001, pp. $442-458$.

Dorrenbacher, Nora, Mastenbroek, Ellen, Toshkov, Dimiter D., "National Parliaments and Transposition of EU Law: A Matter of Coalition Conflict", Journal of Common Market Studies, Vol. 53, No. 5/September 2015, pp. 1010-1026.

Falkner, Gerda, Treib, Oliver, Hartlapp, Miriam, Leiber, Simone, Complying with Europe - EU Harmonisation and Soft Law in the Member States, Cambridge University Press, 2005, p. 4.

Gasmi, Gordana, Pravo i osnovi prava Evropske unije, Univerzitet Singidunum, Beograd, 2010.

Gubby, Helen, English legal terminology, Legal concepts in language, Eleven International Publishing, The Hague, 2016.

Heinemann, Ellen, "The production process of EU directives and their transposition into national law - additional considerations reviewing 'Observing Eurolects. Corpus analysis of linguistic variation in EU law'”, in Laura Mori (ed.), Amsterdam/Philadelphia, John Benjamins 2018. 
Hofmann, Herwig, "Legislation, Delegation and Implementation under the Treaty of Lisbon: Typology Meets Reality", European Law Journal, Vol. 15, No. 4/2009.

Horvatić, Željko, „Pravni sustav Europske unije i pravni temelj njegovog utjecaja na pravne sustave država članica Europske unije," Akademija pravnih znanosti Hrvatske, Vol. IV, 2013, str. 9-16.

Handbook on the Implementation of EU Environmental Legislation, EKRAN Environment and Climate Regional Acession Network, Hulla \& Co Human Dynamics, 2015-2016, pp. 23-24.

Kaeding, Michael, "Determinants of Transposition Delay in the European Union", Journal of Public Policy, Vol. 26, No. 3/2006), p. 232.

Konig, Thomas, Luetgert, Brooke, "Troubles with Transposition? Explaining Trends in Member-State Notification and the Delayed Transposition of EU Directives", B. J. Pol. S. Vol. 39, No. 1/2009, pp. 163-194.

Král, Richard, "On the Choice of Methods of Transposition of EU Directives", European Law Review, Vol. 41, No. 2/2016, pp. 220-242.

Luetgert, Brooke, Dannwolf, Tanja, "Mixing Methods: A Nested Analysis of EU Member State Transposition Patterns", European Union Politics, Volume, Vol. 10, No. 3/2009, pp. 307-334.

Novičić, Žaklina, „Direktna horizontalna primena direktive i opšteg principa zabrane starosne diskriminacije - slučaj Mangold vs. Helm (2005)", Evropsko zakonodavstvo, br. 33-34/2010, str. 234-245.

Pircher, Brigitte, Loxbo, Karl, “Compliance with EU Law in Times of Disintegration: Exploring Changes in Transposition and Enforcement in the EU Member States between 1997 and 2016", Journal of Common Market Studies, Vol. 58, No. 5/2020, pp. 1270-1287.

Piris, Jean-Claude, The Lisbon Treaty - A Legal and Political Analysis, Cambridge University Press, 2010.

Radivojevic, Zoran, „Nadležnost Komisije u postupku predlaganja, usvajanja i sprovođenja akata organa Evropske unije", Revija za evropsko pravo, Vol. 18, No. 1/2016, str. 69-92.

Sansovic, Koraljka, „Koncepti izravne primjene i izravnog učinka u pravu Europske unije", Croatian and Comparative Public Administration, Vol. 20, No. 2/2020, pp. 369-394.

Schütze, Robert, "Delegated' Legislation in the (new) European Union: A Constitutional Analysis", The Modern Law Review, Vol. 74, No. 5/2011, pp. 661-693.

Steunenberg, Bernard, Kaeding, Michael, "As time goes by': Explaining the transposition of maritime directives", European Journal of Political Research, Vol. 48/2009, p. 435. 
Steunenberg, Bernard, Rhinard, Mark, "The transposition of European law in EU member states: between process and politics", European Political Science Review, Vol. 2, No. 3/2010, pp. 495-520.

Steunenberg, Bernard, Voermans, Wim, The transposition of EC directives: A Comparative Study of Instruments, Techniques and Processes in Six Member States, Leiden University, Leiden/Research and Documentation Centre (WODC) of the Ministry of Justice, The Hague, 2005.

Thomas, Martha, "The efficiency of ministries in transposing EU directives: Evidence from Ireland", Public Policy and Administration, Vol. 33, No. 2/2018, pp. 190-215.

Thomson, Robert, Torenvlied, René, Arregui, Javier, "The Paradox of Compliance: Infringements and Delays in Transposing European Union Directives", British Journal of Political Science, Vol. 37, No. 4/2007, p. 686.

Todić, Dragoljub, "Harmonization of legislation of the Republic of Serbia with EU law: open issues and dilemmas", Review of international affairs, 1-2/2014, pp. 96-109.

Tosato, Gian Luigi, Bellodi, Leonardo, (Eds), EU Competition Law, Claeys \& Casteels Publishing, Deventer (The Netherlands) - Leuven (Belgium), 2015.

Vukadinović, Radovan, „Od ugledanja na jevropejske uzore do regionalne harmonizacije - druga strana medalje", Revija za evropsko pravo, Vol. 17, No. 1/2015, str. 5-26.

Walkila, Sonya, Horizontal Effect of Fundamental Rights in EU Law, Europa Law Publishing, Groningen 2016.

Yordanova, Nikoleta, Zhelyazkova, Asya, "Legislative Control over Executive Law-making: Delegation of Quasi-legislative Powers to the European Commission", JCMS: Journal of Common Market Studies, Vol. 58, No. 2/2020, pp. 345-364.

Zhelyazkova, Asya, Yordanova, Nikoleta, "Signalling 'Compliance': The Link between Notified EU Directive Implementation and Infringement Cases", European Union Politics, Vol. 16, No. 3/2015, pp. 408-28. 


\section{DIRECTIVES IN THE LEGAL SYSTEM OF THE EUROPEAN UNION AND THEIR TRANSPOSITION INTO THE INTERNAL LEGAL SYSTEMS OF THE MEMBER STATES}

Summary: The main goal of this paper is to examine the manner in which the place and role of the Directives are regulated in the legal system of the European Union (EU) in the context of the obligation of their transposition into the internal legal systems of the Member States. The paper discusses the hypothesis that the transposition of directives is not clearly regulated, and in some elements leaves room for different interpretations and implementation, including non-compliance with the norms of the directive. The analysis is based on the content of Article 288 of the Treaty on the Functioning of the European Union (TFEU), as well as other relevant provisions of this Treaty and the Treaty on the European Union. Starting from the specificities of the Directives as sources of law, the key elements important for understanding the obligation of their transposition into domestic legal systems are discussed (the concept and meaning of "transposition", purpose, the competence of EU bodies, "result to be achieved", the method of transposition, deadlines for transposition, reporting obligation to the Commission, etc.). The practice of some Member States, as well as various theoretical approaches and difficulties in the process of Directives' transposition, are pointed out. The conclusion states that the transposition of directives into internal legal systems is a systemic issue that should be more precisely regulated having in mind several factors (competencies of this organisation, manner of adopting Directives, their implementation and control over compliance, specificities of the Member States' legal systems in which Directives are transposed, etc.).

Keywords: European Union, EU Directives, transposition of Directives, harmonisation of internal legislation, application of EU legislation, CJEU, candidate countries. 